UPPSALA UNIVERSITET

Working Paper 2008:2

Department of Economics

\title{
Collective Lobbying in Politics: Theory and Empirical Evidence from Sweden
}

Che-Yuan Liang 
Department of Economics

Uppsala University

P.O. Box 513

SE-751 20 Uppsala

Sweden

Fax: $+{ }_{4} 6184711478$
Working paper 2008:2

February 2008

ISSN $1653-6975$

Collective Lobbying in Politics:

Theory and Empirical Evidence from Sweden

Che-Yuan Liang

Papers in the Working Paper Series are published on internet in PDF formats.

Download from http://www.nek.uu.se or from S-WoPEC http://swopec.hhs.se/uunewp/ 


\title{
Collective Lobbying in Politics: \\ Theory and Empirical Evidence from Sweden*
}

February 2008

Che-Yuan Liang ${ }^{\#}$

\begin{abstract}
This paper first formulates a model of how the politicians in a local government collectively lobby to raise intergovernmental grants to their local government. The model identifies a relationship between council size and grants received. I then study this relationship empirically using the distribution of intergovernmental grants to the Swedish local governments. I use a fuzzy regression-discontinuity design that exploits a council size law to isolate exogenous variation in council size and find a large negative council size effect. This pattern provides indirect evidence for the occurrence of lobbying. The direction of the effect could be explained by free-riding incentives in individual lobbying effort contribution caused by a collective action problem in grant-raising among local government politicians.
\end{abstract}

Keywords: lobbying; rent-seeking; collective action problem; group size paradox; local governments; intergovernmental grants; regressiondiscontinuity

JEL classification: D72, D73, D78, H71, H72, H73, H77,

\footnotetext{
* I thank Niclas Berggren, Sören Blomquist, Henrik Jordahl, Lars Lindvall, Per Pettersson-Lidbom, David Strömberg, and seminar participants at IFN, Ratio, and Uppsala University for valuable comments and suggestions. Further, I thank Eva Mörk for providing me most of the data material used and the Jan Wallander and Tom Hedelius Foundation for financial support.

\# Department of Economics, Uppsala University, P.O. Box 513, SE-751 20 Uppsala, Sweden;

che-yuan.liang@nek.uu.se
} 


\section{INTRODUCTION}

Intergovernmental grants are important income sources for local governments in many countries. The functioning of this system is paramount for realizing the benefits of fiscal decentralization. Grants are widely used to internalize interjurisdictional externalities in locally provided goods and to redistribute income. However, the public choice literature suggests that voter choice factors, in particular the tactical concerns by grant-distributing politicians to secure reelection, may affect the distribution as well. Interest groups are another political economy factor of potential importance. Rigid formula-based grant rules and avoidance of discretionary power are measures often taken to avoid the influence of the political economy factors on the distribution. However, in the long run, the distribution rule itself may be subject to political bargaining and manipulation. The presence of distribution rules might therefore not be sufficient.

This paper theoretically and empirically examines the distribution of intergovernmental grants from a local government lobbying perspective. First, I model the process using an interest-group rent-seeking type of model where the local governments are the interest groups and the grants received are the rent. The model relates council size of local governments to grants received. In the empirical application, I investigate the council size effect in the distribution of grants to the Swedish local governments 1981-2006. ${ }^{1}$

I find that increasing local government council size by one politician decreases grants received with 4.5 percent of average share received which corresponds to 0.9 percent of their average income. The estimated council size effect is statistically significant and economically very large. Indirectly, this result constitutes evidence for the presence of lobbying as the pattern can be rationalized as a free-riding effect in lobbying effort contribution among local government politicians, indicating the presence of a collective action problem in grant-raising. However the theory does not allow me to draw any normative conclusions.

The first empirical studies of intergovernmental grants focused on normative economic factors and investigated the distribution of New Deal spending in United States (e.g. Reading 1973). They found that rich states received more than poor states in contrast to the stated equalization objectives. In reaction to this, voter choice models were developed (e.g. Wright 1974) and political factors introduced in the empirical analysis. Since then, numerous papers have found that politics matters (see e.g. Wallis 1996 and Johansson 2003).

\footnotetext{
${ }^{1}$ The municipalities are the local governments of interest and the relevant council is "kommunfullmäktige".
} 
More recently, a few voter choice models have introduced the role of grant-receiving local governments in addition to the grant-giving central government (Grossman 1994 and Borch and Owings 2001). The hypothesis is that districts good at raising votes for the central government receive more grants. A few empirical papers (e.g. Atlas et al. 1995 and Porto and Sanguinetti 2001) have found that politically overrepresented districts with relatively large number of representatives per capita, receive more grants. However, politically overrepresented districts are usually less populous districts. It is therefore often difficult to sort out equity concerns from vote-raising concerns.

This paper also focuses on the grant-receivers rather than the grant-givers. However, my point of departure is the lobbying rather than the vote-raising aspects. Lobbying activities are normally studied in the interest-group rent-seeking literature. My approach therefore integrates the two fields by recognizing that local government can function as an interest group, and this could be fruitful for both fields as I will argue.

The occurrence of lobbying activities is of big interest in itself. Many theories assume or predict the occurrence of lobbying activities. But since such activities often are disguised, suitable cases to study the phenomenon are not abundant. I argue that the grant distribution case is a suitable case where eventual lobbying might be detected. The existing empirical literature on rent-seeking is mainly focused on lobbying by companies (e.g. Goldberg and Maggi 1999 and Gawande and Bandyopadhyay 2000). Although lobbying can occur by political actors as well, this area of research is in its infancy. One pioneering paper is Sørensen (2003) who finds that local governments that contact the central government more often get more grants. Another paper is Knight (2005) who finds that districts with people in important legislative committees get more grants. However, none of the papers interpret such activities in the light of a rent-seeking model.

The grant-distribution lobbying situation is a case of collective rent-seeking, since the rent is given to a group rather than to individuals. Olson (1965) argues that under such conditions, group members free-ride on other members' lobbying efforts. He believes that this collective action problem is much worse in larger groups than smaller groups, resulting in a group size paradox where small groups are more successful in absolute terms despite their numeral inferiority. Several papers have modeled collective rent-seeking games (e.g. Tullock 1980 and Riaz et al. 1995). Some studies the conditions under which the group size paradox holds (e.g. Nitzan 1991 and Esteban and Ray 2001). In addition to detect lobbying, the grant distribution case may shed some light on the collective action problem. 
Free-riding behavior in politics is an issue that mostly appears in the common pool literature. Theory (Weingast et al. 1981) predicts a positive relationship between local government council size and spending. The intuition is that each politician fully internalizes spending on her constituents, but only a fraction of its costs since these are shared by all constituents, resulting in overspending from each local government's point of view. Most empirical papers support the theory (e.g. Gilligan and Matsusaka 1995 and Baqir 2002). There may be a similar free-riding effect on the income side and this is the effect that I identify in my model. Rather than overspend, the free-riding effect may cause the politicians to underinvest in income-raising activities from each local government's point of view.

This paper may not only contribute to our understanding of lobbying, but also to our understanding of the political economy of intergovernmental grants. Rent-seeking models have stronger micro-foundation than the recent voter-choice-based models of intergovernmental grants that focus on the role of local governments. This enables me to relate properties of the lobbying process such as the grant-spending structure and the lobbying effort-cost function to the distribution.

In the empirical application, I use a discontinuous council size rule in Swedish law to isolate exogenous variation in the council size of the Swedish local governments. The law creates a natural experiment and is used to create a fuzzy regression-discontinuity design that can be implemented with IV. This approach was first used by Pettersson-Lidbom (2007) to examine the common pool problem. The regression-discontinuity design is particular credible for causal inference since it exploits an explicit source of exogeneity rather than just eliminating apparent sources of endogeneity. On the down side is that the method usually requires large data sets or produces low precision.

The paper is organized as follows. Next section formulates a collective lobbying model and examines when the free-riding incentives are likely to cause a group size paradox. Section three describes the Swedish intergovernmental grants system and why it seems reasonable to expect significant lobbying activities to take place here. Section four outlines the regressiondiscontinuity design and motivates the non-standard measures taken in this study. Section five overviews the data material and gives a graphical analysis. Section six presents the regression results along with a number of specification tests. Last section concludes and discusses the interpretation of the results. 


\section{THEORY}

For a long time, it was thought that the inefficiency of monopoly only consists of the reduction in total consumer and producer surplus. However, Tullock (1967) argued that since the monopoly rent is attractive to potential monopolists, they are willing to lobby to obtain these benefit which leads to a misallocation of resources even if no monopoly is actually established. "Rent-seeking" is now the standard term used to denote these activities. Here, I present a collective lobbying model based on the rent-seeking models in Nitzan (1991) and Esteban and Ray (2001). Two features in the model differ from the basic rent-seeking model. First, the rents are given to groups rather than individuals. Second, the rents are divisible among the groups and not necessarily awarded to only one group.

\subsection{The Model}

Let $m$ be the number of local governments and $n_{i}$ the council size, i.e. the number of council members or politicians, in local government $i . N=\sum_{i=1}^{m} n_{i}$ is then the total number of local government politicians in the country. $m, n_{i}$, and $N$ are exogenously given. First, there is a lobbying phase where the local government politicians, indexed by $j$, individually choose their lobbying effort contribution $l_{i j}$ to their local government's collective lobbying effort $l_{i}=\sum_{j=1}^{n_{i}} l_{i j}$ to raise grants. Aggregate lobbying in the country is then denoted $L=\sum_{i=1}^{m} l_{i}$.

Although the politicians choose their efforts individually, we allow lobbying not only to be conducted by the individuals separately, but also jointly at the local government level, with the restriction that the collective lobbying effort is the sum of the individual efforts. However, I assume that each politician cares about and represents one distinct group of constituents in their local government. The groups do not overlap, but need not cover everyone. ${ }^{2}$ The politicians base their effort choice on two factors: the expected amount of resources they secure for their constituents and the disutility of their own effort. I work with an additively separable decision utility function that is linear in expected secured resources, but with a general effort cost function $c\left(l_{i j}\right)$.

\footnotetext{
${ }^{2}$ This assumption is standard in the empirical political economy literature (see e.g. Baqir 2002).
} 
Esteban and Ray (2001) discuss the likely functional form of $c\left(l_{i j}\right)$ in different situations. Their conclusion is that it is likely to be linear when the lobbying inputs are monetary contributions without liquidity constraint, but a power function of higher order than one otherwise. I restrict $c\left(l_{i j}\right)$ to be a quasi-convex function, which accommodates the cases discussed.

The second phase is the grant distribution phase. The central government distributes grants $g_{i}$ to local government $i$ depending on their collective lobbying effort $l_{i}$ and in total $G=\sum_{i=1}^{m} g_{i}$, where $G$ is exogenously given. ${ }^{3} i$ receives a share of grants $\pi_{i}$ according to the proportional distribution rule:

$$
\pi_{i}=\frac{g_{i}}{G}=\frac{l_{i}}{L}
$$

The last phase is the spending phase. Grants received by the local governments are spent on private goods and each dollar spent is only valued by one group of constituents. ${ }^{4}$ Each politician secures a share of grants received for her constituents. The size of this share depends on her influence over how to spend the grants. The influence is determined by the sharing-rule:

$$
s_{i j}\left(l_{i j}\right)=e \frac{l_{i j}}{l_{i}}+(1-e) \frac{1}{n_{i}} .
$$

$e$ is the effort relevance parameter and determines how large part of the influence that is effort based, i.e. depends on the relative effort contribution of politician $j$ in $i: l_{i j} / l_{i}$. The rest of the influence, $l-e$, is "shared" on the egalitarian principle i.e. over which all politicians have equal saying. $\boldsymbol{l}_{i j}$ is a vector of the lobbying efforts for each $j$ in $i$.

Knowing how grants are distributed between and spent within local governments, the decision utility $u_{i j}$ of a politician in the first lobbying phase can be formulated as

$$
u_{i j}=y_{i j}+s_{i j}\left(l_{i j}\right) g_{i}-c\left(l_{i j}\right) \text {, }
$$

where $y_{i j}$ are non-lobbying game resources that she secures for her constituents.

\footnotetext{
${ }^{3}$ There are of course other kinds of lobbying related as well as non-lobbying related determinants of grants. These are simply excluded from $g_{i}$ and $G$. The importance of lobbying and whether the model presented here could be used to interpret the outcome of such activities is an empirical issue that I turn to later.

${ }^{4}$ Most local government resources are spent on private goods such as health care, education, and care of elderly.
} 


\subsection{Equilibrium Properties}

Each politician takes the lobbying efforts of others as given when choosing her effort. Inserting equations (1) and (2) into equation (3) and deriving the first order condition with respect to $l_{i j}$ gives the interior choice of lobbying effort condition

$$
\left[e\left(1-\frac{l_{i j}}{L}\right)+(1-e)\left(1-\frac{l_{i}}{L}\right)\right] \frac{G}{L}-c^{\prime}\left(l_{i j}\right)=0 .
$$

In equilibrium all politicians within a local government behave symmetrically and equation (4) is satisfied for everyone. This is equivalent to imposing the following condition:

$$
n_{i} l_{i j}=l_{i}=\pi_{i} L
$$

To get the equilibrium aggregate lobbying effort $L$, we have to insert equation (5) into (4), sum over local governments and make use of the following condition:

$$
\sum_{i} \pi_{i}=1
$$

The case with a linear cost function $c\left(l_{i j}\right)=l_{i j}$ corresponds to Nitzan (1991) and the case with an egalitarian sharing rule $e=0$ resembles Esteban and Ray (2002).

There are two notions of how grant distribution depends on council size. We could ask how grants received vary when council size changes within a given equilibrium, holding aggregate lobbying effort constant, or across equilibria, letting the aggregate lobbying effort adjust in response to the change. For comparisons within a cross section, the within approach suffices. For comparisons across cross sections, the across approach is needed. The comparative statics results turn out to be the same and are summarized in Proposition 1.

\section{PROPOSITION 1}

a) The relationship between share of grants received and council size is negative inducing a group size paradox when the sharing rule is sufficiently egalitarian and when the cost elasticity of effort is sufficiently low.

b) Increasing the effort relevance in the sharing rule or increasing the cost elasticity of effort has a (weakly) positive effect on the relationship between share of grants received and council size, which makes the group size paradox less likely.

Proof. See Appendix. 
The relationship between share of grants received and council size generally depends on council size, and may be nonlinear and have ambiguous signs (see equation A3 in Appendix). A sufficient condition for linearity is when the marginal cost is constant (make use of equation 6 and A2 in Appendix). A sufficient condition for a positive relationship across local governments is $\inf \left(\eta_{c}\right)>1$ (see equation A2 in Appendix). If the cost function is a power function, this requirement corresponds to a higher power than quadratic.

An interesting measure is grant dissipation, i.e. how much is spent on lobbying relative to the grant: $L / G$. When the resources used for lobbying is not monetary, we have to interpret this measure carefully. It is the valuation that the politicians place on their effort had they valued each unit of effort equal to each unit of grants that they secure for their own constituents. With full grant dissipation, a linear effort cost function, and full effort relevance, the politicians would not perceive any benefits from grants since the effort they put would just be worth the grants they secure for their own constituents. The dependence of grant dissipation on parameters is summarized in Proposition 2.

PROPOSITION 2. Grant dissipation increases with effort relevance and decreases with marginal effort cost.

Proof. See Appendix.

Propositions 1 and 2 completely describe the effects of effort relevance and effort cost. In the "basic case" with an egalitarian sharing rule and a linear effort cost, there is a negative relationship between share of grants received and council size (see equation A3 in Appendix). The result is caused by larger free-riding incentives in larger councils which give rise to a group size paradox. If effort relevance increases, free-riding decreases, which increases lobbying and grant dissipation. But since free-riding are more severe in larger councils, lobbying increases more in these councils, which works against the group size paradox. If effort cost increases, lobbying decreases, which decreases grant dissipation. But since each politician lobby more in smaller councils due to more free-riding in larger councils, higher effort cost strikes smaller councils more, which works against the group size paradox.

The direction and size of the relationship between share of grants received and council size cannot tell us whether grant dissipation is high or low. When the group size paradox is less strong or reversed the cause might be either or both high effort relevance and high effort cost. The former causes low and the latter high grant dissipation. 


\subsection{Other Theoretical Issues}

I have formulated a lobbying model that relates properties of the lobbying process to the outcome. The choice of which factors to include in the model is based on their relevance in the grant distribution context, analytical simplicity, and their importance in the previous rentseeking literature. There are however many other lobbying related factors that might influence the outcome pattern, and these might be of importance in practice.

One factor frequently analyzed in the rent-seeking literature (e.g. Katz et al. 1990) is the publicness of grants received, i.e. how large share is spent on public goods valued by all constituents in a local government. Increasing publicness reduces free-riding incentives which enhances the success of larger groups and works against the group size paradox.

Other omitted factors are scale effects. Specialization and coordination are scale effects in council size, where the former favors larger and the latter smaller councils. There may also be scale effects in lobbying effort such as fixed costs, which benefit ambitiously lobbying councils. Fixed costs enforce the direction of any council size effects. Scale effects in lobbying effort may also take place at the politician level rather than the local government level. This can however be taken care of by the general effort cost function in the model.

Another issue not dealt with in the model is potential heterogeneity in lobbying power between local government politicians. The central government might be more responsive to lobbying effort exerted by some politicians than others. New politicians might e.g. not have the same contact network as experienced politicians. Further, local government representatives of the same party as the governing party in the central government might have larger influence than others, an idea that can be motivated by Cox and McCubbins' (1986) voter choice model where the central government favors local governments governed by the same party. Yet another possibility is that local government politicians in the governing local government coalition might lobby more efficiently.

My model does not give a clear prediction of the direction of the relationship between share of grants received and council size. An empirical analysis can therefore not test the model in an ordinary sense. However, an empirical regularity in the distribution of grants in the form of a council size effect would constitute a "distortion" and is an interesting issue in itself since it raises efficiency issues. I use the word "distortion" in a weak sense to denote a bias toward local governments with certain council sizes. If we could remove this distortion, keeping everything else equal, this would be desirable. However, this distortion could be part of a second best outcome with the first best being practically infeasible. 
In any case, such a distortion would require an explanation, and this is what my collective lobbying model provides. Rather than addressing the efficiency issues, I investigate the council size effect as an indirect way to study lobbying. For this purpose, I do not need a full-fledged model. The model only serves to identify a possible outcome pattern of lobbying. As mentioned, there are also other lobbying-related factors that have additional effects on the direction of the pattern. However, this only stresses the need of an empirical investigation of the council size effect as a way to study lobbying. I also realize the importance of nonlobbying related factors, although these are not studied in this paper.

The empirical investigation starts from the recognition that lobbying is a plausible perhaps the only plausible - explanation to an eventual council size effect on grants received. However, we need to ensure that the effect is causal and direct. Both tasks are mainly empirical ones. There is however a theoretical reason to suspect that an eventual council size effect on grants may work through an intermediate channel, the spending channel, as the common pool theory (Weingast et al. 1981) predicts a positive council size effect on spending due to another kind of free-riding among council members. If spending in turn affect grants, there could be a causal, yet indirect, effect of council size on grants received which is common-pool driven, and not lobbying driven. This prescribes an assessment of this channel of causation in the empirical analysis, something that I will do.

If there is no distortion in the distribution of grants in the form of a council size effect, the evaluation in terms of lobbying becomes more difficult. Such a result would be consistent with the absence of lobbying as well as a case with non-distortionary lobbying where effort relevance and other factors cancel out the free-riding incentives exactly. The question of the presence of lobbying must therefore be inconclusive in this case.

\section{INSTITUTIONAL BACKGROUND}

Sweden has three levels of governments: the central government, the counties and the municipalities. There are 21 counties (24 before 1998) and 290 municipalities in 2006 . The local governments are major actors in the Swedish economy. The counties are responsible for public health care and the municipalities for day care, education, and care of the elderly. Their share of the national GDP spending is around 20 percent, one third spent by the counties and two thirds by the municipalities. They employ around 25 percent of the total Swedish workforce. In this study, the municipalities are the local governments of interest. 
Each municipality has a council. The size of those is partly determined by law, which prescribes minimum requirements depending on the number of eligible voters: $31,41,51$ and 61 for municipalities with less than 12000, more than 12,000, 24,000, and 36,000 eligible voters prior to the last election. Council size may only change in the first year after an election. Elections dates are fixed and elections are held each third year before 1994 and each fourth year after that. I use data from the period 1981-2006 spanning seven election periods with election years in 1982, 1985, 1988, 1991, 1994, 1998, and 2002. Pre-eighties data are not very useful because of extensive municipal amalgamations during the previous decades.

Although the municipalities have far-reaching self-governance rights including the right to tax, a significant share, about 20 percent, of their resources consists of intergovernmental grants. The evolution of the distribution of net grants to the municipalities in 2006 SEK (1.0 2006 USD $\approx 7.82006$ SEK) per capita over time is illustrated in box plots in Figure 1 . The boxes contain the medians and the first and third quartiles. The whiskers mark the first and ninth deciles. Extremum values are left out. The figure shows that grants are unevenly distributed across municipalities and that the variation in distribution is large over time. We also see that some local governments are net contributors to the system.

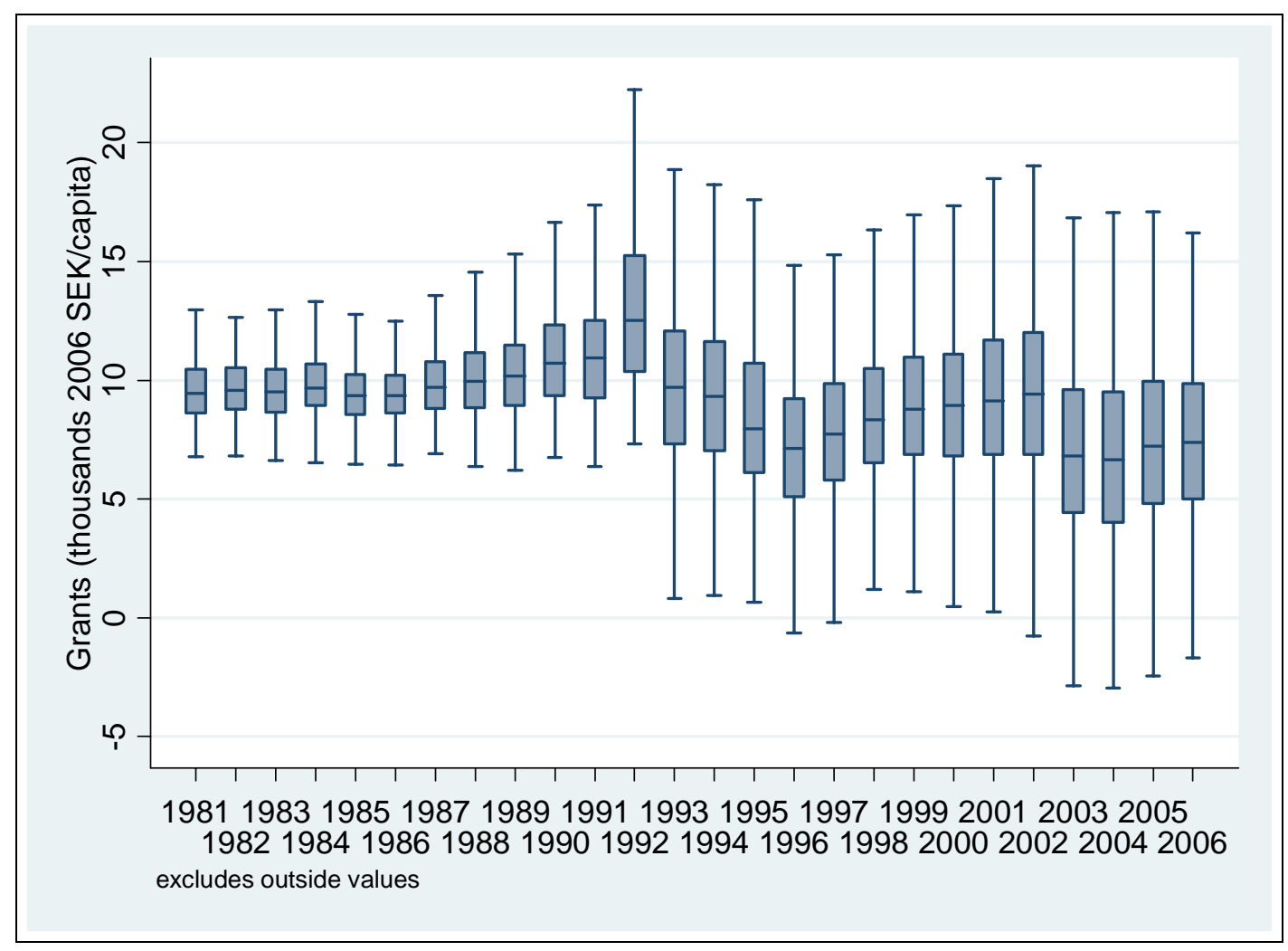

Figure 1. Box plots of per capita grants to the local governments 
There have been several changes in the rules governing the distribution and use of grants. In 1980, in the beginning of the sample period, there were two main kinds of grants: income equalizing and targeted grants. The former were organized such that the municipalities were divided into five groups based on geography and demographics. Municipalities in each group were guaranteed an amount to reach the same minimum per capita tax base. The latter were discretionarily distributed for specific purposes and were larger than the former. In 1986 another component was introduced where municipalities with large per capita tax bases had to contribute to the system through a fee. In addition, supplementary grants were introduced for municipalities with urgent needs. These grants constituted two percent of all grants. In 1988 a twelve-group division replaced the five-group division.

In 1993 a new three-component system was introduced with an income-equalizing, a cost-equalizing and a migration part. The municipalities received formula-based individual weights in the new income-equalizing system. Further, most discretionary targeted grants became general formula-based. In 1996 the migration component was abolished and two new components introduced: general and transition grants. The income- and cost-equalizing component also became fully self-financed. A large number of municipalities became net contributors due to this. The new system received a lot of critique, especially with respect to its large extension and complexity. Significant changes now occurred almost every year. A number of targeted grants were e.g. introduced in 2000.

In 1999 a committee was appointed to evaluate the system and propose new reforms. This culminated in a major reform in 2005 and the introduction of a five-component system. The previous income- and cost-equalizing systems were largely held intact and new transition grants were granted. Two new components were put in place: structural grants to compensate abolished grants and regulatory grants to control the overall level of the whole system for the central government. See Söderström (1998) and Almenberg (2005) for further details on the evolution of the system.

The municipalities have had large discretion in how to use the grants during the sample period. Since the reform of 1993, the discretion increased further when several previously targeted grants became general grants. Much of targeted grants can also be shifted away, although most empirical papers find large fly paper effects proving that targeted grants often achieve their intentions (e.g. Dahlberg et al. forthcoming, finds large effects for Sweden).

The municipalities are further divided into districts governed by bureaucrats. Since the local government councils contain politicians from different districts as well as parties, they do represent different interests and constituents to some degree. They have a possibility to 
benefit certain constituents by affecting the spending allocation between different sectors or by changing taxes and fees for different kinds of services. Although the politicians do not directly represent a certain district, the district apportionment provides an additionalgeographical instrument - to canalize municipal spending to certain groups of constituents.

The main conclusion about the Swedish intergovernmental grant system is that there were some, although rather limited, discretion in the distribution a given year, but large discretion in how the rules were formed. From this, Johansson (2003) infers that the institutional setting allowed the central government to use grants tactically. She examines and also finds evidence for vote-purchasing behavior in the distribution of grants in Sweden for the period 1981-1995. Dahlberg and Johansson (2002) reach a similar conclusion regarding a temporary grant program where the discretionary power of the central government was more evident. Further, Jordahl (2002) finds that the Swedish voters did reward such behavior.

As mentioned in the introduction, the opposite side of the coin - the lobbying efforts of the local governments - has more seldom been examined. However, since the central government seems to have distributed grants discretionarily, there were potential payoffs for lobbying activities by the municipalities. I believe that the right conditions for the presence of lobbying were in place. The large variation in distribution over municipalities and time, the frequent changes in distribution rules (three major reforms in 1993, 1996, and 2005, and another three larger reforms in 1986, 1988, and 2000 during the sample period), the large discretion in how to spend grants received, and the possibilities for individual politicians to affect municipal finance are factors that ultimately makes these activities potentially profitable, both for a municipality as a whole as well as for individual politicians in a municipality.

In practice these activities could be conducted toward the central government or some of its politicians or bureaucrats, as well as the public committees or some of its investigators frequently appointed to evaluate the system and propose reforms. Lobbying could take place individually, jointly at the municipal level, or jointly between municipalities with similar interests. There are several lobbying channels. One is to put direct pressure on the central government through letters, phone calls and personal contact. Such behavior is documented in Norway in Sørensen (2003). Since many central government politicians are former municipality politicians, the two networks are often well-connected.

The influence may also be indirect through e.g. different organizations. The municipalities may e.g. lobby the Swedish association of local authorities and regions, which is consulted by the central government in municipality related issues, especially before new 
reforms (Jansson 1990). Another channel is public opinion that can be affected through the media. There are several examples of municipality politician signed debate articles (e.g. Klintbom 1994). Most notably has the self-financing component that requires some municipalities to pay a fee often been criticized for being a "Robin Hood tax". There have also been threats in the press to bring the functioning of the system to court (Sörbring 2000).

\section{EMPIRICAL STRATEGY}

Council size generally covaries with a large number of other variables. Isolating exogenous variation is therefore difficult, a problem often discussed in the empirical literature on the common pool problem in politics. One partial remedy is to add fixed effects (e.g. Gilligan and Matsusaka 1995). However, these do not take care of time-varying omitted variables, such as voter preferences. Another approach is to use instrumental variables. Baqir (2002) uses e.g. historical council size to instrument for current council size. But if the omitted variables are persistent, this instrument does not remove all endogeneity. I use the statutory council size law mentioned in the last section to isolate exogenous variation in council size. The law creates a natural experiment and can be used for identification in a regression-discontinuity design. This approach is first used by Pettersson-Lidbom (2007). Before turning to method and specifications, next subsection first describes the variables that will be used.

\subsection{Description of Variables}

I use yearly local government data from 1981-2006, most of them available at Statistics Sweden. I have chosen to use the longest available period because most lobbying possibilities lie in affecting the long-run rules as described in the last section. There could therefore be a large noise in the council size effect during shorter time intervals. This is also appropriate since the method used usually requires large data sets to reach satisfactory precision levels.

The main variables used are described in Table 1 . The dependent variable in the analysis is share of grants received: Grants. It is expressed in percentage of average local government share. Average Grants is hundred percent of average share. The scaling in percentage follows from the model which relates share of grants received to council size. The normalizing in terms of average share simplifies the interpretation of the estimates. 
Table 1. Description of variables

\begin{tabular}{l|l}
\hline Variable & Description \\
\hline Grants & Grants received in percentage of average municipal share: $\mathrm{g}_{\mathrm{i}} / \mathrm{G}^{*} \mathrm{~m}$ \\
Council & Number of municipality council members \\
Voters & Eligible voters scaled as Grants \\
\hline Z12 & Dummy: 1 if eligible voters $>12,000,0$ otherwise \\
$\mathrm{Z} 24$ & Dummy: 1 if eligible voters $>24,000,0$ otherwise \\
Z36 & Dummy: 1 if eligible voters $>36,000,0$ otherwise \\
\hline
\end{tabular}

I use net intergovernmental grants rather than specific components for several reasons. First, all rules may change and none of the components are truly non-discretionary. Lobbying may therefore affect the distribution of many different grants. Second, different components may be simultaneously adjusted. Third, few components have consistently existed for longer periods. Using specific components would therefore reduce the amount of data that I could use. Data at the component specific level is also difficult to get access to.

Another issue is how to deal with net contributors. Net contribution could only occur in the model if we allow negative amounts of lobbying, which is clearly unrealistic. Empirically, I choose to exclude net contributors before calculating the grant shares, which is to assume that their outcomes are exogenously determined. The point estimates are insensitive to their exclusion, but the standard errors are reduced somewhat.

The independent variable of main interest is council size, Council. Since grants are distributed in the beginning of a year, the relevant lobbying could take place earliest the previous year. I therefore use the previous year council size. The main covariate is Voters which is the share of eligible voters at the last election, i.e. the number of eligible voters scaled in the same way as Grants. The number of eligible voters is the assignment variable that by law partly determines council size. However, I only have post-election data, which might differ somewhat from the pre-election data on which the implementation of the law is based on. A few values on the variable have been trimmed since they are obviously on the wrong side of the council size requirement thresholds. ${ }^{5}$

Further, the observations are divided into four council size groups described by the three group dummies $Z 12, Z 24$ and $Z 36$. When the number of eligible voters pass a council size requirement threshold $x^{*} 1,000$, the group dummy $Z x$ switches sign from zero to one. The three thresholds are at 12,000, 24,000, and 36,000 eligible voters. I use the council size group dummies as instrumental variables.

\footnotetext{
${ }^{5}$ If a post-election number violates the law when a council size has changed, I trim the figure to be just on the right side. I trim thirteen observations. This does not affect point estimates but reduces standard errors.
} 


\subsection{The Regression-Discontinuity Specifications}

The council size law creates three thresholds where average council size increases abruptly, if the law has a real impact on council size. The basic idea with regression-discontinuity is to compare observations just below and just above a threshold. There, a negligible difference in the number of eligible voters produces a significant difference in council size. The observations therefore differ, on average, only with respect to council size. This variation is exogenous since the assignment into different council size groups is locally random. For an introduction to the regression-discontinuity design, see Lee (2008).

The design can be implemented by comparing sample means just above and below the thresholds. This requires the intervals around the thresholds to be small. Another approach that I mainly use, which also uses data further away from the thresholds and increases precision, exploits the fact that the number of eligible voters fully determines the assignment into the council size groups. As this assignment variable is the only variable systematically related to the thresholds, council size is exogenous around the thresholds conditional on it. By controlling for its continuous effect on outcome, we can use the discontinuous variation in council size that the thresholds produce to identify a causal council size effect.

When the law is sharp, i.e. fully determines council size, a sharp regressiondiscontinuity design using a simple OLS regression can be implemented. However, the law only partly determines council size. It is e.g. not restrictive for local governments with council size well above the minimum council size requirements of their closest threshold. In such a case, we can implement a fuzzy regression-discontinuity design using an IV specification. See Imbens and Lemieux (2007) for a general treatment on how to implement a regressiondiscontinuity design and the difference between the sharp and the fuzzy designs.

I use Z12, Z24, and Z36 as instrumental variables. Since the instruments are linearly independent they can be used to construct Wald-estimates at each threshold (Angrist 1991). To improve precision and to obtain a single estimate, I assume that the council size effect is constant across council size, thresholds, and units (like in e.g. van der Klaauw 2002). The model predicts such a relationship when the effort cost function is linear. This single estimate is a weighted average of the Wald-estimates. As a specification check, I later check this assumption by calculating threshold specific effects. My main IV specification estimated with 2-SLS is described by the following equations:

$$
\text { Grants }_{i, t}=\beta_{\text {Council }} \text { Council }_{i, t-1}+\boldsymbol{\beta}_{\text {Voters }}{ }^{\prime} \boldsymbol{f}\left(\text { Voters }_{i, t-1}\right)+v_{i}+\varepsilon_{i, t} \text {, }
$$


Council $_{i, t-1}=\alpha_{z 41} Z 41_{i, t-1}+\alpha_{z 51} Z 51_{i, t-1}+\alpha_{z 61} Z 61_{i, t-1}+\alpha_{\text {Voters }}{ }^{\prime} \boldsymbol{f}\left(\right.$ Voters $\left._{i, t-1}\right)+\eta_{i}+e_{i, t-1}$.

$i$ indexes local government and $t$ indexes year. Equation (7) is the second-stage structural equation and equation (8) is the first-stage reduced-form equation. $\boldsymbol{f}\left(\operatorname{Voter}_{i, t-1}\right)$ is a control function vector in the assignment variable and contain polynomial terms in Voters $s_{i, t-1 .} v_{i}$ and $\eta_{i}$ are local government fixed effects, and $\varepsilon_{i, t}$ and $e_{i, t-1}$ are idiosyncratic error terms.

Two features in my setup are not standard in the regression-discontinuity literature. First, I scale my assignment variable in the same way as the dependent variable. Second, I include fixed effects. These two measures turns out to improve the low precision when using more conventional specifications like in e.g. Lee (2008), and can be motivated theoretically in this application.

Although we only need to control for the assignment variable for consistency, there is still the issue of which functional form to use. Even if the standard approach to include a simple polynomial is enough for consistency, using the right functional form usually improves precision and stability. This issue becomes increasingly important when the assignment variable is discrete as discussed by Card and Lee (2008). This is the case here as the number of observations provided by local government data is much smaller than the individual level data often used in regression-discontinuity contexts, and since the assignment variable only changes after election years. If the number of eligible voters affects the grants received, we expect the shares of the variables to be related. Therefore, I scale the assignment variable in the same way as Grants, that is as Voters. To enter the assignment covariate flexibly, I follow the standard practice and include a polynomial in this covariate up to a fourth order.

This scaling also accounts for time effects since it adjusts for the variation in aggregate grants and aggregate number of eligible voters over time as aggregate shares cannot vary over time. The usual measure to include time dummies to take care of time effects is more suspicious as that implies that aggregate shares are allowed to vary over time. I do not scale the council size variable, which would not matter as there is very little relative variation in aggregate shares in this variable over time.

The main reason to include other covariates than the assignment polynomial is that they could improve precision by reducing the error variance. However, since they also reduce the amount of variation as the number of degrees of freedom decreases, the net effect on precision is theoretically ambiguous. In the present case, fixed effects retain a large amount of the 
useful variation around the thresholds as I will examine in the next section, and turn out to improve precision significantly, even compared to the inclusion of other kinds of covariates.

With fixed effects, identification is mainly based on local governments that change council size when passing a threshold. Such a within regression-discontinuity strategy is used and advocated by e.g. Hoxby (2000) and Pettersson-Lidbom (2007). In addition to improved precision, the choice of functional form for the assignment variable becomes less vital since any time-invariant influence is partialled out. Pooling data over the three thresholds to produce a single council size estimate also becomes unproblematic as any constant differences across thresholds are removed.

In the regression-discontinuity design, the observations close to the thresholds are most useful for identification. Observations further away could be used to improve the fit of the assignment polynomial and precision. However, observations too far away might differ fundamentally from those at the thresholds. Therefore I choose to exclude population outliers. My highest threshold is at 36,000 eligible voters, and I restrict my sample to $<60,000$ eligible voters. The results are insensitive to varying this limit somewhat. Henceforth I refer to the outliers (and net contributor) excluded basic full sample, as the "full sample".

As already mentioned, another method to account for the influence of the assignment variable is to restrict the sample narrowly around the thresholds. From an IV standpoint, the instruments become weaker for observations further away. In the fixed effect case, using a "threshold sample" eliminates cases where a large change in the assignment variable produces a large change in council size, which is in line with the idea of using observations where a negligible change in the assignment variable produces a sizeable change in the main variable. This measure tries to make most use of the source of exogeneity that the thresholds provide, rather than only to eliminate possible sources of endogeneity. According to Hoxby (2000), only observations close to the thresholds are "non-suspicious". The threshold sample approach trades off precision for potential bias. I combine this approach with the control function approach in several parts of the analysis by limiting my sample to \pm 10 or \pm 5 percent of the threshold values around the thresholds. ${ }^{6}$

\footnotetext{
${ }^{6}$ The ten percent sample contains observations in the intervals $10,800-13,200,21,600-26,400$, and $32,400-$ 39,600 eligible voters. Corresponding intervals for the five percent sample are $11,400-12,600,22,800-25,200$, and $34,200-37,800$ eligible voters.
} 


\section{DESCRIPTIVE ANALYSIS}

\subsection{Summarizing the Data}

Summary statistics are reported in Table 2. Means, standard deviations, minimum and maximum values are reported for the (outliers and net contributor excluded) full sample (without parenthesis) and the five percent sample (in parenthesis). There are 6764 observations for the 25 years 1981-2006 with observations from 276 of the 290 local governments in 2006. The five percent sample contains 674 observations from 267 local governments.

Table 2. Summary statistics out the full and five percent sample

\begin{tabular}{l|cccc}
\hline Variable & Mean & Std. Dev. & Min & Max \\
\hline Grants & 76.002 & 54.069 & 0.362 & 573.365 \\
& $(93.923)$ & $(43.782)$ & $(1.941)$ & $(269.188)$ \\
Council & 45.227 & 8.807 & 30 & 75 \\
& $(50.087)$ & $(6.172)$ & $(35)$ & $(61)$ \\
Voters & 71.149 & 54.266 & 9.404 & 283.982 \\
& $(93.880)$ & $(41.483)$ & $(47.295)$ & $(182.488)$ \\
\hline
\end{tabular}

Notes: Five percent sample values are in parenthesis. There are 6764 observations in the full sample and 674 observations in the five percent sample.

The means for Grants and Voters are lower than 100 percent of the average because of the omission of population outliers. The standard deviations are roughly of equal size as the means. The smallest local governments have about one tenth of the average population and the largest local governments three times the average population. The span in grants received is larger than this. The average local government has 45.2 politicians and the variation in this variable much smaller. The five percent sample contains on average larger local governments with larger councils that receive more grants, and is a more homogenous sample.

Note that minimum Grants is positive because of the exclusion of the net contributors. The monetary figures used to calculate Grants reflects the accounting incidence and not the real incidence which includes the hidden financing of the system in the form of general taxes. The variation in accounting incidence is likely much smaller than variation in the real incidence, since the degree of self-financing varies over time which produces accounting differences without any real impact. The real incidence is a too complicated issue to be analyzed here. We should keep this distinction in mind and be especially careful when interpreting quotient comparisons such as "increasing council size with $x$ doubles grants". 
In the within regression-discontinuity design, only local governments that pass a threshold are potentially "directly" identifying. Those that also change council size are directly identifying. Not directly identifying local governments contribute indirectly to the identification as they help to fit the covariates. I henceforth drop the term "directly", and also refer to the indirectly identifying local governments as non-identifying. Table 3 identifies the potentially identifying local governments. The first column shows the thresholds and the council size requirements, the second column the number of potentially identifying local governments, the third column the number of identifying ones, and the fourth column the number of identifying observations in the identifying local governments.

Table 3. Identifying observations

\begin{tabular}{c|ccc}
\hline Thresholds & Cross the threshold & Change council size & Identifying obs. \\
\hline 12,000 eligible voters & 20 & 4 & 99 \\
& $(18)$ & $(4)$ & $(45)$ \\
24,000 eligible voters & 20 & 14 & 344 \\
& $(18)$ & $(12)$ & $(143)$ \\
36,000 eligible voters & 9 & 6 & 139 \\
& $(6)$ & $(3)$ & $(40)$ \\
\hline Sum & 49 & 24 & 582 \\
& $(42)$ & $(19)$ & $(228)$ \\
\hline
\end{tabular}

Notes: Five percent sample values are in parenthesis. There are 6764 observations in the full sample and 674 observations in the five percent sample.

Only one sixth of the local governments pass a threshold and only half of those also go through a council size change, which gives 24 identifying local governments; 4 at the first, 14 at the second, and 6 at the third threshold. This corresponds to 582 identifying observations, which make 8.6 percent of the full sample - a small share, but not remarkably few observations in absolute numbers. Most identifying local governments are kept in the five percent sample although the number diminishes to 228 observations or 33.8 percent of that sample. The small share of identifying observations cause relatively low precision and is a cost we have to pay to isolate exogeneity with the data-hungry regression-discontinuity design.

Identifying council changes can either be upward or downward changes. In the former, the increase takes place to meet new stricter requirements when the number of eligible voters passes a threshold from below. In the latter, the decrease is made possible by new less strict requirements when the number of eligible voters passes a threshold from above. About three fourth of the directly identifying changes are upward ones. One downward change is a 
delayed change, i.e. the change was made in a later election than the earliest election allowed. Three identifying changes are non-forced, i.e. not directly made to comply with the new requirement. ${ }^{7}$ None of the local government passes two different thresholds. 18 local governments in the full sample and 2 in the five percent sample were involved in some kind of redistricting during the sample period. None of them are identifying however, and the results are insensitive to their exclusion.

\subsection{Graphical Analysis}

A graphical procedure to preliminary investigate the relationship outlined by the IV specification in equation (7) and (8) is to plot the reduced-form relationships. I plot the firststage (reduced-form) relationship between council size and the number of eligible voters in Figure 2, and the reduced-form relationship between share of grants received and the number of eligible voters in Figure 3. The $\mathrm{x}$-axis is divided into 240 non-overlapping bins each spanning 250 eligible voters. A marker is used to mark the local average of the observations in a bin along the $\mathrm{y}$-dimension and the midpoint of the bin along the $\mathrm{x}$-dimension. The figures show two series of plots. The hollow circles plot the non-identifying observations and the solid triangles the identifying observations in the five percent sample. The thresholds are marked with dashed lines at the boundaries of two bins.

Figure 2 shows a positive and continuous first-stage relationship for the non-identifying observations. It is difficult to distinguish a threshold effect from the overall positive effect. The pattern is mainly driven by the cross-sectional variation. However, passing a threshold has a larger positive and rather discontinuous influence on the council size for the identifying observations. This pattern is mainly driven by the within variation and provides graphical evidence that the thresholds are relevant in the within regression-discontinuity design which supports the instrument relevance criteria in IV. In fact, adding the non-identifying observations to the identifying ones to make use of the cross-sectional variation for identification would weaken the visible discontinuous effect of the instruments significantly as the thresholds has little impact on the non-identifying observations. This indicates that the within design retains most of the useful variation, and that it is likely to be more efficient.

\footnotetext{
${ }^{7}$ Delayed and non-forced changes are not obviously exogenous since they are not made to directly comply with the law. However, they should still be included in IV regressions, which compare all potentially directly identifying observations on each side of a threshold to measure the impact of the law.
} 


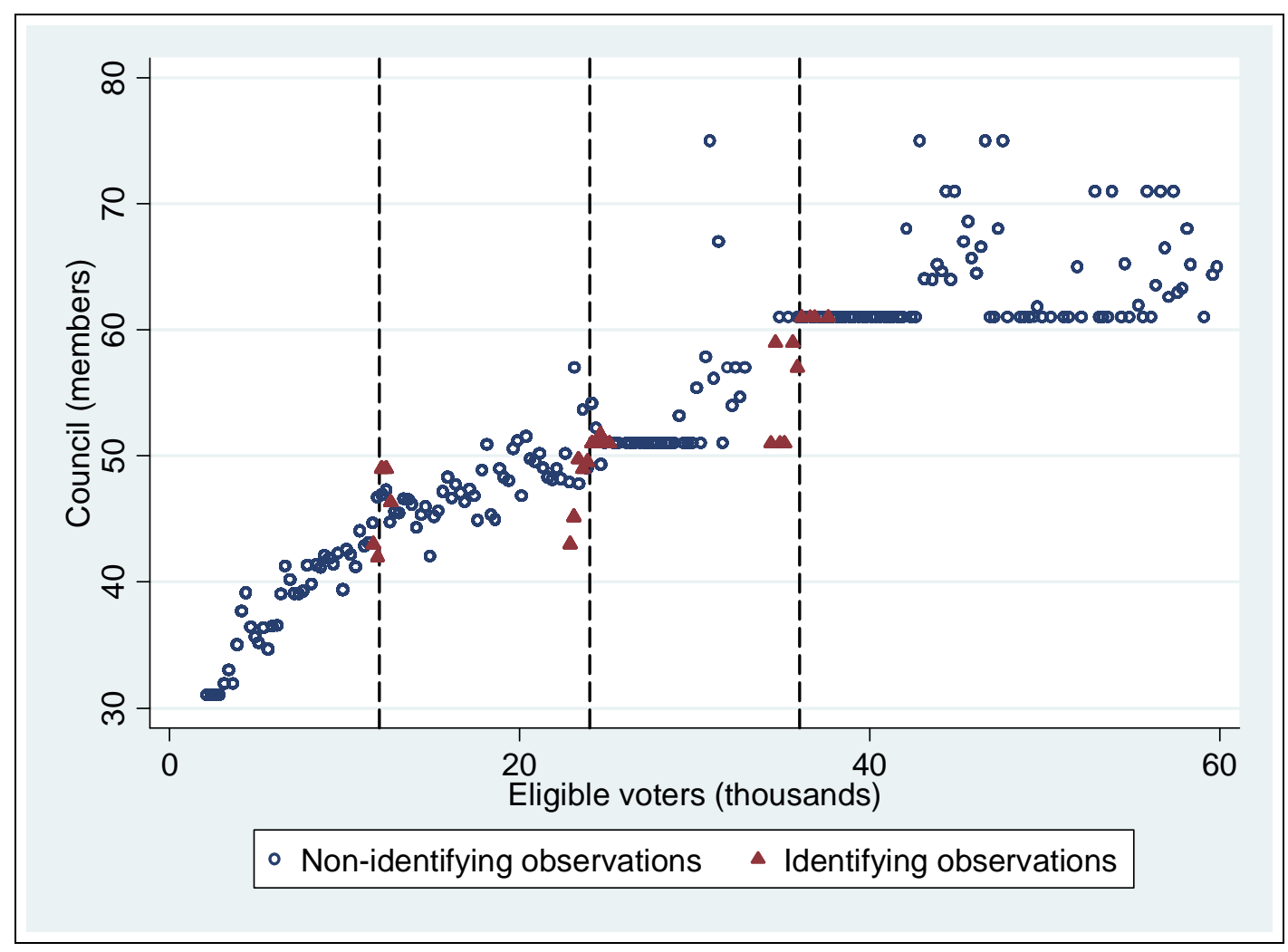

Figure 2. Local averages of Council by bins

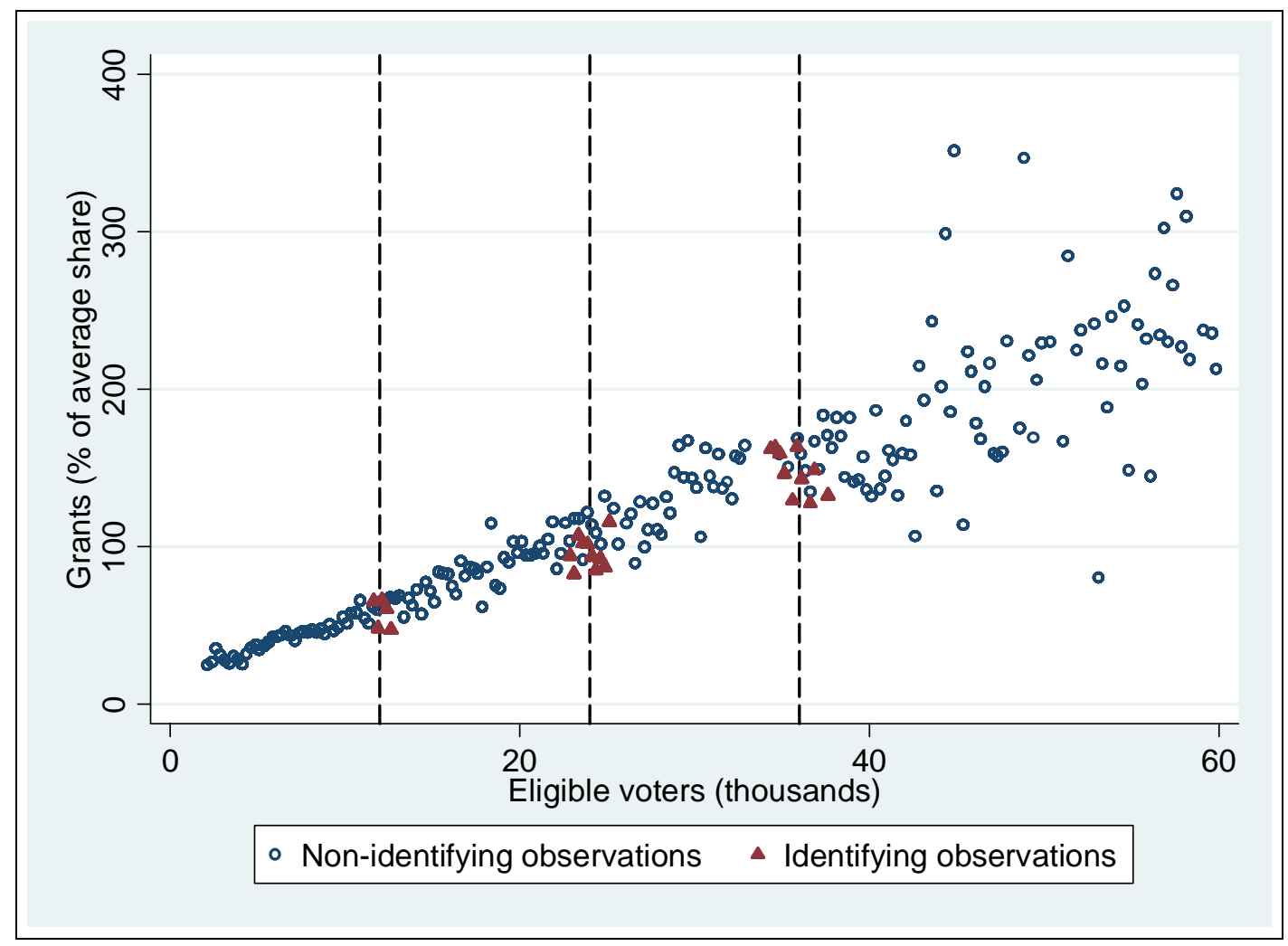

Figure 3. Local averages of Grants by bins 
Figure 3 also reveals a positive and continuous reduced-form relationship for the nonidentifying observations. In contrast, there is negative, or at least much less positive, relationship for the identifying observations, when a threshold is passed. The natural noise is however large; the variation in grants received between neighbor non-identifying dots with similar average number of eligible voters are often as large as the negative threshold effect for the identifying observations. The visual evidence for the identifying observations is nevertheless suggestive; the council size law seems to cause council size to grow as a threshold is passed, which in turn seems to reduce share of grants received.

\section{REGRESSION RESULTS}

\subsection{Main Results}

The main results of the regressions described by equation (7) and (8) are reported in Table 4. Each cell reports an estimate of Council from one separate regression and is an estimate of the council size effect on share of grants received. Along the horizontal dimension, I vary the order of polynomials in Voters. Along the vertical dimension, I vary specification along other dimensions. I report Huber-White robust standard errors allowing for clustering at the local government level in parenthesis. These standard errors are conservative and roughly double the non-clustered values here. This adjustment is however appropriate since the error term might be serially correlated within local governments.

Table 4. Main results

\begin{tabular}{l|ccccc}
\hline Dep: Grants & {$[1]$} & {$[2]$} & {$[3]$} & {$[4]$} & {$[5]$} \\
Polynomials & None & $1^{\text {st }}$ & $2^{\text {nd }}$ & $3^{\text {rd }}$ & $4^{\text {th }}$ \\
\hline OLS & $-1.261^{* * *}$ & $-1.072^{* * *}$ & $-1.085^{* * *}$ & $-1.080^{* * *}$ & $-1.047^{* * *}$ \\
& $(0.252)$ & $(0.237)$ & $(0.231)$ & $(0.234)$ & $(0.234)$ \\
RD Full & $-4.761^{* * *}$ & $-4.525^{* *}$ & $-4.415^{* *}$ & $-4.694^{* * *}$ & $-4.897^{* * *}$ \\
& $(1.601)$ & $(1.825)$ & $(1.980)$ & $(1.801)$ & $(1.786)$ \\
RD 10\% & $-3.187^{* *}$ & $-3.817^{* * *}$ & $-3.696^{* * *}$ & $-3.599^{* * *}$ & $-3.622^{* * *}$ \\
& $(1.345)$ & $(1.386)$ & $(1.365)$ & $(1.364)$ & $(1.322)$ \\
RD 5\% & $-4.675^{* *}$ & $-5.242^{* * *}$ & $-5.118^{* *}$ & $-4.500^{* * *}$ & $-4.523^{* *}$ \\
& $(1.964)$ & $(1.994)$ & $(2.105)$ & $(1.932)$ & $(1.907)$ \\
\hline
\end{tabular}

Notes: Each estimate is an estimate of Council from one separate regression. Polynomials refer to polynomials in Voters. Huber-White robust standard errors allowing for clustering within local governments are in parentheses. * significant at $10 \% ;{ }^{* *}$ significant at $5 \% ; * * *$ significant at $1 \%$. 
A point estimate of $-x$ means that another politician decreases grants received with on average $x$ percent of average local government share (and not on average $x$ percent of grants received in a local government). This implies, but is not equivalent with, that an additional politician decreases grants received with $x$ percent in the representative local government. For local governments receiving a small share of grants, the same value of $x$ implies a larger relative impact than for local governments receiving a large share of grants, as each percent of the average share is relatively larger.

The simple OLS full sample reference estimates of the regression of Grants $t_{t}$ on Council $_{t-1}$ including the assignment polynomial and fixed effects are reported in the $O L S$ row. The estimated council size effect is negative and around -1.0 percent per politician across polynomial orders and statistically significant at the one percent level. The three following rows report the regression-discontinuity estimates, first the full sample estimates in the $R D$ Full row, then the ten percent sample estimates in the $R D 10 \%$ row, and finally the five percent sample estimates in the $R D 5 \%$ row.

The full sample regression-discontinuity point estimates are still negative, but around -4.5 percent per politician, which is more than four times larger than the OLS equivalents. This effect is stable across polynomial orders and mostly statistically significant at the one percent level, although standard errors are much larger than when using OLS. The ten percent sample estimates show somewhat smaller estimated effects that converge toward -3.5 percent per politician for the higher polynomial order specifications. Further narrowing the sample to five percent increases the estimated effects back to -4.5 percent per politician when including higher polynomial orders. Standard errors decreases a bit as we go from the full to the ten percent sample, but increases back as we further reduce the intervals to five percent.

Adding assignment polynomials has relatively small effects on estimated effects, indicating that fixed effects partials out most of the mainly cross-sectional influence of the assignment variable. Adding further orders above four has also little additional effects. The results are insensitive to alternative ways to fit the assignment polynomial such as to only use the potentially identifying observations in the samples or including non-identifying observations between the thresholds in the threshold samples.

Now, I report a number of common IV test statistics. The variation across polynomial order specifications is small, and I report the averages of the statistics across the specifications. A Durbin-Wu-Hausman test of the endogeneity of Council using the $O L S$ and $R D$ Full specifications gives $\chi^{2} \approx 40.5$. The null of exogeneity is rejected at the five percent level which indicates that instruments are needed. An overidentification test gives Hansens- 
J values $2.1,1.9$, and 0.25 for the full, ten, and five percent samples respectively. The joint null of instrument exogeneity and correct model specification cannot be rejected. An F-test of instrument relevance gives autocorrelation robust F-values: 8.6, 7.4, and 4.8 for the full, ten, and five percent samples respectively. This indicates that there are some weak instrument concerns, which I will address later in this section.

The estimated effects vary somewhat across the samples, even if the standard errors are too large to reject equality of estimated effects. I find the five percent sample estimates to be the most credible ones, since narrowing the sample around the thresholds reduces potential bias, and because the efficiency loss of using this smaller sample is small in this application. Henceforth, I also do my specification tests in the next subsections on that sample.

The most credible estimate of -4.5 in the five percent sample means that increasing council size with one politician decreases percentage of average share of grants received with 4.5 percent. Grants make up around 20 percent of the average local government's income which corresponds to 182.1 millions 2006 SEK (23.3 millions 2006 USD). An additional politician therefore decreases grants with 0.9 percent of average local government income, i.e. 8.2 millions 2006 SEK (1.1 millions 2006 USD). For the full sample used in the analysis, the average council size is 45.2 , has standard deviation 8.8 , and minimum and maximum values 30 and 75 . The average council size change is 6.7. The estimated effect therefore implies that the variation in council size across and within local governments has an economical significant impact on income. Due to the relatively large standard errors, the point estimates should however be considered rough estimates of the council size effect.

\subsection{Sensitivity Tests}

The results from a number of sensitivity tests on the five percent sample are reported in Table 5, which follows the same format as previously. If we have estimated a causal council size effect, adding further control variables should not affect estimated effects. To check this, I include several time-varying demographic controls typically considered to be independently determined. These are: tax base, to reflect equality concerns; population, as considerations were given to scale economies; population under 18 and population over 65 , since education and elderly care were two major responsibilities of the local governments; and population changes, since some grants compensated for migration patterns. The controls are scaled in shares as the dependent variable, but the results are similar if we use a per capita scaling. 
Table 5. Sensitivity tests

\begin{tabular}{l|ccccc}
\hline Dep: Grants & {$[1]$} & {$[2]$} & {$[3]$} & {$[4]$} & {$[5]$} \\
Polynomials & None & $1^{\text {st }}$ & $2^{\text {nd }}$ & $3^{\text {rd }}$ & $4^{\text {th }}$ \\
\hline Controls & $-5.033^{* *}$ & $-5.080^{* *}$ & $-4.599^{* *}$ & $-3.918^{*}$ & $-3.909^{*}$ \\
& $(2.192)$ & $(2.282)$ & $(2.201)$ & $(2.050)$ & $(2.064)$ \\
Spending & $-4.757^{* * *}$ & $-4.840^{* *}$ & $-4.737^{* *}$ & $-4.067^{* *}$ & $-4.075^{* *}$ \\
& $(1.847)$ & $(1.949)$ & $(2.057)$ & $(1.967)$ & $(1.930)$ \\
\hline $2^{\text {rd }}$ lag & $-4.156^{* *}$ & $-4.420^{* *}$ & $-4.419^{* *}$ & $-4.443^{* * *}$ & $-4.045^{* *}$ \\
& $(1.753)$ & $(1.790)$ & $(1.819)$ & $(1.691)$ & $(1.647)$ \\
$3^{\text {th }}$ lag & $-4.081^{* *}$ & $-4.119^{* *}$ & $-3.896^{* *}$ & $-3.764^{* *}$ & $-3.614^{* *}$ \\
& $(1.693)$ & $(1.769)$ & $(1.725)$ & $(1.626)$ & $(1.527)$ \\
$4^{\text {th }}$ lag & $-3.939^{* *}$ & $-3.876^{*}$ & $-3.364^{*}$ & -2.982 & -3.504 \\
& $(1.895)$ & $(2.012)$ & $(1.979)$ & $(1.971)$ & $(2.190)$ \\
$5^{\text {th }}$ lag & -2.357 & -2.278 & -1.448 & -0.960 & -2.156 \\
& $(1.947)$ & $(2.001)$ & $(2.142)$ & $(2.368)$ & $(3.021)$ \\
$6^{\text {th }}$ lag & -1.925 & -1.740 & -1.056 & -0.472 & -1.946 \\
& $(2.272)$ & $(2.194)$ & $(2.314)$ & $(2.531)$ & $(2.994)$ \\
\hline $1^{\text {st }} 4^{\text {rd }}$ lags & $-5.201^{* *}$ & $-5.140^{* *}$ & $-4.965^{* *}$ & $-4.777^{* *}$ & $-4.936^{* *}$ \\
& $(2.148)$ & $(2.122)$ & $(2.123)$ & $(1.915)$ & $(1.975)$ \\
Election term & $-4.544^{* *}$ & $-4.833^{* * *}$ & $-4.685^{* * *}$ & $-4.147^{* * *}$ & $-4.576^{* * *}$ \\
& $(1.849)$ & $(1.714)$ & $(1.732)$ & $(1.555)$ & $(1.675)$ \\
\hline
\end{tabular}

Notes: Each estimate is an estimate of Council from one separate regression. Polynomials refer to polynomials in Voters. All regressions are done on the five percent sample. Huber-White robust standard errors allowing for clustering within local governments are in parentheses. * significant at $10 \% ; * *$ significant at $5 \% ; * * *$ significant at $1 \%$.

The estimates with controls are reported in the Controls row. The estimated effects are rather insensitive to the inclusion of these controls supporting that I have identified a causal council size effect. As the dependent variable is scaled in shares, the estimates of the controls are not easily interpretable and left out. Another heterogeneity issue is whether the council size effect is homogenous across local governments with different demographics. To check this I divide the identifying observations into two groups, one with low and one with high values on each one of the controls, and run regressions that use either the high or the low sample. The estimated effects between the high and low samples are consistently close to each other.

Is the causal council size effect on grants a direct effect, or is it a secondary effect working through local government spending, driven by a common pool effect? I address this issue by including spending as a covariate, which removes the effect of council size that works through the non-predetermined spending variable. Again, spending is scaled in shares, although the results are similar when a per capita scaling is used. The results are reported in the Spending row. The insensitivity to this inclusion supports that I have identified a direct council size effect on grants. However, the analysis remains agnostic about whether there also is a common-pool driven direct council size effect on spending, or whether the direct council size effect on grants leads to an indirect effect on spending. 
Next, I examine the composition of long-run and short-run effects. This is interesting since most of the lobbying opportunities lie in affecting the long-run formulas. The natural way to examine dynamics by including further lags is not very attractive when using IV as these variables increase the number of endogenous regressors. High auto-correlation in council size also makes it difficult to sort out the effects precisely.

The approach I take indirectly evaluates the different effects by replacing all first lagged independent variables in equation (7) and (8) with further lagged variables. These results are reported in the $x^{\text {th }}$ lag rows, where $x$ denote the lag used. When using first lags in the main specification, we allow the effect of a council size change on grants received to take place immediately in the following year. The estimated effect is the average yearly effect in the post-change years relative to the pre-change years. This is the most inclusive measure capturing all short-run and long-run effects. ${ }^{8}$ When using the $x^{\text {th }}$ lag, what we get is loosely speaking the additional long-run effects after $x$ years. More exactly, we get the average yearly effect during the post-change period less the first $x$ post-change years relative to the average of the pre-change period and the first $x$ post-change years.

The estimated additional council size effects decrease rather immediately as lags further back in time are used. After four years the additional effects are no longer significant. Much of the effects therefore realizes quite fast. This does not mean that the effects disappear in the long-run, just that the additional long-run effects are small compared to the immediately realized short-run and long-run effects.

I also explicitly model the long-run effects, by including weighted averages of the last four years' values for the independent variables. This allows the lagged effects to occur up to four years back. The estimated effect can be interpreted as the effect of changing council size and then holding the council size constant for four consecutive years. The results are reported in the $1^{\text {st }}-4^{\text {th }}$ lags row, and are similar to main first lag results.

Another way to incorporate long-run effects explicitly is to aggregate data by election periods, which allows the influence to be election-period-wise. Since election periods are three years long prior to and four years after 1994, and because I only have data for two out of three years in the first election period, the years receive different weights. Except for this, the estimates have a similar interpretation as the main yearly specification. The results are reported in the Election term row, and are close to the main yearly results.

\footnotetext{
${ }^{8}$ However, when there are several council size changes in a local government, the long-run post-second change effects of the first change is not included. But there are few multiple changes in the sample.
} 


\subsection{Threshold Specific Estimates}

I have until now assumed a homogenous council size effect across the thresholds, as I have pooled data over all thresholds, and estimated a single council size effect. The plausibility of this assumption can be evaluated by estimating independent threshold specific effects. I do this by calculating distinct-IV estimates for each of the thresholds, using a five percent subsample around one threshold at a time and the instrument relevant for that threshold, as well as fixed effects and an assignment polynomial. This procedure also eliminates eventual weak instrument bias, since this bias disappears as the number of instruments decreases toward the number of endogenous regressors according to Angrist and Kreuger (2001). I also look at the reduced-form estimates to get an intuitive understanding of the results.

The threshold specific estimates are reported in Table 7. I report the first-stage (reduced-form) OLS estimates of the instruments on Council in the First Zx rows, the reduced-form OLS estimates of the instruments on Grants in the Reduced Zx rows, and the distinct-IV 2-SLS estimates of Council on Grants in the $I V Z x$ rows, where $Z x$ denotes the relevant instrument and threshold. Each cell reports the estimates from one separate regression. The distinct-IV point estimates for a threshold could also be obtained by dividing the reduced-form point estimates with the first-stage point estimates.

Passing each threshold has a positive effect on council size that is statistically significant according to the first-stage estimates (which was previously illustrated in Figure 2). Passing the first threshold increases council size with around one politician and passing each of the last two thresholds has around three times larger effects. Since only around 50 percent of the local governments that pass a threshold also change council size, the average change among changers, is double the estimated average change.

Passing each of the thresholds has a negative effect on grants received according to the reduced-form estimates (which was previously illustrated in Figure 3). The effects are larger for the last two thresholds than for the first threshold, but only statistically significant at the five percent level for the second threshold. This is the case because there are many fewer identifying observations around the other thresholds (as shown in Table 3).

The distinct IV-estimates are all negative as passing each threshold increases council size but decreases grants received. This is strong support for a general negative council size effect as it occurs at three different thresholds with different average council sizes. All estimates are also all around the single main estimated effect of -4.5 , which provides evidence for the constant council size effect assumption in the main specification. 
Table 6. Threshold specific estimates

\begin{tabular}{|c|c|c|c|c|c|}
\hline Polynomials & $\begin{array}{c}{[1]} \\
\text { None }\end{array}$ & $\begin{array}{l}{[2]} \\
1^{\mathrm{st}}\end{array}$ & $\begin{array}{l}{[3]} \\
2^{\text {nd }}\end{array}$ & $\begin{array}{l}{[4]} \\
3^{\text {rd }}\end{array}$ & $\begin{array}{l}{[5]} \\
4^{\text {th }}\end{array}$ \\
\hline First Z12 & $\begin{array}{l}1.075^{*} \\
(0.620)\end{array}$ & $\begin{array}{l}1.029 * \\
(0.601)\end{array}$ & $\begin{array}{l}1.100 * \\
(0.601)\end{array}$ & $\begin{array}{l}1.025^{*} \\
(0.598)\end{array}$ & $\begin{array}{l}1.006^{*} \\
(0.583)\end{array}$ \\
\hline First Z24 & $\begin{array}{c}2.620 * * * \\
(0.884)\end{array}$ & $\begin{array}{c}2.952^{* * * *} \\
(0.904)\end{array}$ & $\begin{array}{c}2.795^{* * * *} \\
(0.814)\end{array}$ & $\begin{array}{c}2.726^{* * *} \\
(0.794)\end{array}$ & $\begin{array}{c}2.711^{* * *} \\
(0.783)\end{array}$ \\
\hline First Z36 & $\begin{array}{c}2.374 \\
(1.451)\end{array}$ & $\begin{array}{l}2.811^{*} \\
(1.595)\end{array}$ & $\begin{array}{l}2.929 * \\
(1.592)\end{array}$ & $\begin{array}{l}2.884^{*} \\
(1.625)\end{array}$ & $\begin{array}{l}2.884^{*} \\
(1.625)\end{array}$ \\
\hline Red Z12 & $\begin{array}{l}-4.108^{*} \\
(2.402)\end{array}$ & $\begin{array}{l}-4.256^{*} \\
(2.454)\end{array}$ & $\begin{array}{l}-4.733^{*} \\
(2.446)\end{array}$ & $\begin{array}{l}-4.308^{*} \\
(2.522)\end{array}$ & $\begin{array}{l}-3.946 \\
(2.625)\end{array}$ \\
\hline Red Z24 & $\begin{array}{c}-11.423^{*} \\
(5.606)\end{array}$ & $\begin{array}{c}-15.680 * * * \\
(4.066)\end{array}$ & $\begin{array}{c}-14.732^{* * *} \\
(5.162)\end{array}$ & $\begin{array}{c}-14.629 * * * \\
(5.134)\end{array}$ & $\begin{array}{c}-14.270^{* *} \\
(5.293)\end{array}$ \\
\hline Red Z36 & $\begin{array}{c}-14.038^{*} \\
(6.984)\end{array}$ & $\begin{array}{c}-7.717 \\
(10.224)\end{array}$ & $\begin{array}{l}-10.809 \\
(10.361)\end{array}$ & $\begin{array}{l}-13.880 \\
(9.623)\end{array}$ & $\begin{array}{l}-13.880 \\
(9.623)\end{array}$ \\
\hline IV Z12 & $\begin{array}{l}-3.820 \\
(3.113)\end{array}$ & $\begin{array}{l}-4.135 \\
(3.382)\end{array}$ & $\begin{array}{l}-4.302 \\
(3.231)\end{array}$ & $\begin{array}{l}-4.204 \\
(3.316)\end{array}$ & $\begin{array}{l}-3.922 \\
(3.233)\end{array}$ \\
\hline IV Z24 & $\begin{array}{l}-4.360^{*} \\
(2.296)\end{array}$ & $\begin{array}{c}-5.312^{* * *} \\
(2.036)\end{array}$ & $\begin{array}{c}-5.271^{* *} \\
(2.462)\end{array}$ & $\begin{array}{c}-5.366^{* *} \\
(2.476)\end{array}$ & $\begin{array}{c}-5.264^{* *} \\
(2.533)\end{array}$ \\
\hline IV Z36 & $\begin{array}{l}-5.912 \\
(5.188)\end{array}$ & $\begin{array}{l}-2.745 \\
(4.218)\end{array}$ & $\begin{array}{l}-3.690 \\
(4.638)\end{array}$ & $\begin{array}{l}-4.813 \\
(4.906)\end{array}$ & $\begin{array}{l}-4.813 \\
(4.906)\end{array}$ \\
\hline
\end{tabular}

Notes: The estimates are estimates of the instruments $Z x$ in the First $Z x$ and Red $Z x$ rows and of Council in the $I V Z x$ rows, where $Z x$ denotes the relevant instrument and threshold. Each estimate comes from one separate regression. Council is the dependent variable in the First $Z x$ rows and Grants is the dependent variable in the other rows. OLS is used in the First $Z x$ and Red $Z x$ rows, and 2-SLS is used in the $I V Z x$ rows. Polynomials refer to polynomials in Voters. All regressions are done on the five percent sample around the relevant threshold. Huber-White robust standard errors allowing for clustering within local governments are in parentheses. * significant at $10 \% ;{ }^{* *}$ significant at $5 \% ; * * *$ significant at $1 \%$.

Another way to get threshold specific estimates is to estimate reduced-form equations including instruments and observations from all three thresholds, and then construct threshold specific Wald-estimates by dividing the reduced-form estimates with each other. In fact the main single estimated effects are weighted averages of such Wald-estimates. I report the distinct-IV results as standard errors cannot be obtained for the Wald-estimates. The Waldestimates are however close to their distinct-IV counterparts.

The similar distinct-IV estimates also indicate that the instruments are exogenous. If another variable than council size also changes discretely when a threshold is passed, this change rather than the council size change may be the cause of the change in grants received. However, if such a variable seriously biases the estimates at one threshold, the estimated council size effects would differ significantly across thresholds. This is essentially what is tested in an overidentification test. The threshold specific estimates illustrate why instrument exogeneity could not be rejected previously.

Another specification check is to estimate reduced-form estimates at several placebo thresholds. I use threshold samples within five percent of the threshold values and a third 
order assignment polynomial, and plot the results, which are insensitive to adding further polynomial orders, in Figure 4. The hollow circles show the first-stage estimates of how council size changes, and the solid triangles the reduced-form estimates of how share of grants received changes, as a threshold is passed. I connect the estimates with lines across the thresholds. The thresholds are placed out with regular intervals of 4,000 eligible voters up to 40,000 eligible voters. ${ }^{9}$ This interval length prevents overlapping supports across thresholds, and includes the three real thresholds at 12,000, 24,000, and 36,000 eligible voters, which are marked with dashed lines, as well as seven placebo thresholds, with thresholds below the lowest, above the highest, and in between the three real thresholds.

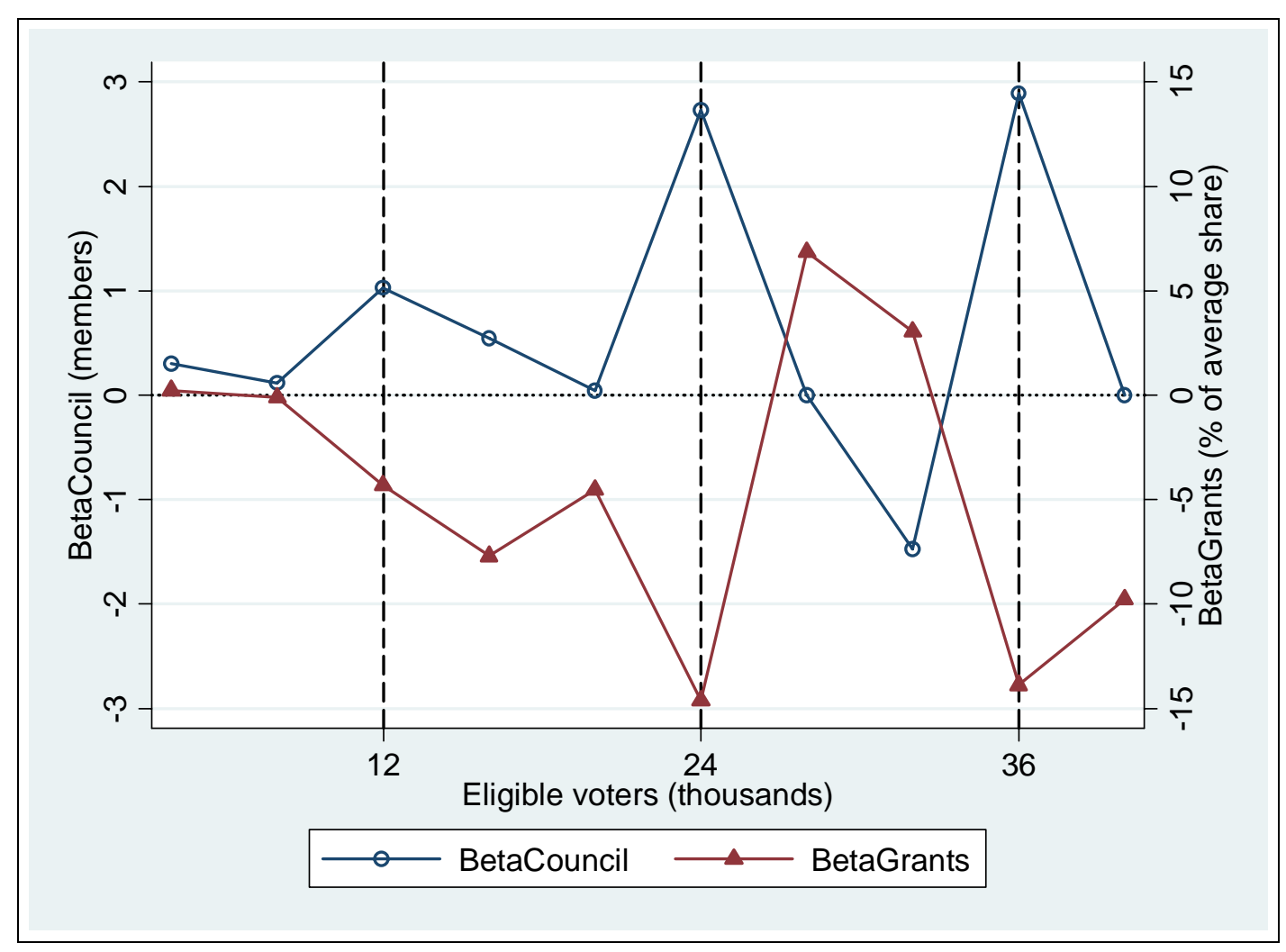

Figure 4. Placebo thresholds

At all three real thresholds, council size increases and grants received decreases, which just illustrates that the estimated negative council size effect. At the placebo thresholds on the other hand, council size and grants received increases sometimes and decreases other times. These changes are mostly smaller than the changes at the real thresholds indicating that something systematic is going on at the real thresholds. The "noise" is however sometimes

\footnotetext{
${ }^{9}$ Above 40,000 eligible voters there are very few observations.
} 
rather large at the placebo thresholds, especially at the later thresholds. A fact that contributes to this pattern is that there are relatively few observations at those thresholds as more than half the sample contain observations with less than 12,000 eligible voters. However, when there is a larger positive noise in one plot, this is usually accompanied by a larger negative noise in the other plot. The plots therefore mirror each other quite well, and even the placebo thresholds suggest that council size and grants received move in opposite directions, albeit for unknown "noisy" reasons.

\section{CONCLUDING DISCUSSION}

I have formulated a collective lobbying model that predicts a certain relationship between council size and grants received. An indirect way to study lobbying is to examine this relationship empirically, and I did this for the distribution of intergovernmental grant to the Swedish local governments the last 25 years. I found that increasing local government council size with one politician decreases grants received with 4.5 percent of average share, which corresponds to 0.9 percent average local government income.

This pattern could be seen as evidence for the occurrence of lobbying activities as the model shows that such distortions are likely products of such activities. Further, the negative relationship suggests that there are important free-riding incentives among local government politicians that outweigh the importance of other factors like effort relevance, effort cost, spending on public goods, and scale effects that may reduce such incentives. There is therefore a collective action problem in lobbying effort contribution to raise grants to the local government, which results in a group size paradox.

Is the estimated council size effect unreasonably large? To investigate this, I compare the effect with the variation in share of grants received in the whole system, including the outliers and the net contributors. To explain a variation of 1.0 standard deviations in grants received requires a variation of 3.1 standard deviations in council size. The extremum values of grants received span 3,300 percent of average share, whereas the span in extremum values of council size implies a variation of 320 percent. Further, average change in grants received is 9.6 percent per year and the largest change 1,860 percent per year. The average council size change explains 0.51 percent, the average change among the changers 30.1 percent, and the extremum change 135 percent. Council size can therefore only explain a small part of the extremely large variation in grants received between and within local governments. 
The estimated council size effect may apply to local governments with 10,000 to 100,000 inhabitants (among which roughly two thirds are voters) and 30 to 75 politicians. However, as discussed in the theory section, there are a large number of potentially important institutional aspects. The design of the system and the bureaucratic tradition are therefore probably major determinants of the outcome. More empirical research on other countries is needed before any conclusions can be drawn about the importance of these other aspects.

This paper has implications for the common pool literature. I have shown that the council size effect on grants received identified here is not working through spending, and therefore not common-pool driven. If grants received constitute a large part of local government spending, the reverse pattern may however be important, i.e. there could be a council size effect on spending that works through grants received, which could be lobbying driven. In such an instance, the empirical common pool literature needs to remove this channel of causation before interpreting the effect as a common pool effect.

The presence of lobbying and council size distortions should be of great concern. Lobbying activities are generally considered wasteful activities as they are non-productive and distort resource allocation. However, such activities also convey (often correct) information to the central government. In the standard monopoly rent-seeking case, such information has no value as the free-market price mechanism carry all necessary information for efficient allocation. In the case of intergovernmental grants, there is no price mechanism, and such information may help the central government allocate resources more efficiently and equitably. It is therefore not clear whether limiting lobbying would improve welfare.

Although lobbying by the politicians could improve efficiency by revealing important information, the way it takes place by inducing a council size distortion cannot be efficient from a first best perspective. According to theory, lobbying may take place in a council-size distortion-free way. Whether the present situation yet constitutes a second best outcome (with first best unattainable), cannot be answered here. Without an elaborated welfare analysis, this paper can therefore not give any policy recommendations. In fact, the council size distortion neither reveals anything about the extent of lobbying, as the size of this distortion is not related to grant-dissipation in a simple way.

Rent-seeking theories have flourished for decades, and lobbying is a phenomenon often studied theoretically. There are however still very few empirical papers. How extensive are these activities, and what kind of patterns do they give rise to? This paper identifies the intergovernmental grant distribution system as a suitable investigation object to indirectly study lobbying and outlines how an investigation can be conducted in this special case. 


\section{APPENDIX}

Proof of Proposition 1. Inserting equation (5) into equation (4) gives

$$
\left[e\left(n_{i}-1\right)+1-\pi_{i}\right] \frac{G}{L}-n_{i} c^{\prime}\left(\frac{\pi_{i} L}{n_{i}}\right)=0
$$

Treating $L$ as fixed in equation (A1), totally differentiating with respect to $\pi_{i}$ and $n_{i}$, and then rearranging gives the following within equilibrium result:

$$
\frac{\partial \pi_{i}}{\partial n_{i}}=\frac{\pi_{i}}{n_{i}} \frac{e-1+\pi_{i}+\eta_{c}\left[e\left(n_{i}-1\right)+1-\pi_{i}\right]}{\pi_{i}+\eta_{c}\left[e\left(n_{i}-1\right)+1-\pi_{i}\right]},
$$

where $\eta_{c}=\frac{l_{i j} c^{\prime \prime}\left(l_{i j}\right)}{c^{\prime}\left(l_{i j}\right)}$ denotes the cost elasticity of effort. Quasi-convexity of $c\left(l_{i j}\right)$ gives $\eta_{c} \geq 0$, with equality for the linear case.

To see Proposition 1a for the within equilibrium case, rewrite equation (A2) as:

$$
\frac{\partial \pi_{i}}{\partial n_{i}}<0 \Leftrightarrow 1-\pi_{i}-e>\eta_{c}\left[e\left(n_{i}-1\right)+1-\pi_{i}\right]
$$

The relationship between share of grants received and council size is negative when $e$ and $\eta_{c}$ are sufficiently low. High $e$ or $\eta_{c}$ might however reverse the group size paradox. To see Proposition $1 \mathrm{~b}$ for the within equilibrium case, differentiate equation (A2) with respect to the parameters:

$$
\begin{aligned}
& \frac{\partial\left(\frac{\partial \pi_{i}}{\partial n_{i}}\right)}{\partial e}=\frac{\pi_{i}}{n_{i}} \frac{\pi_{i}+\eta_{c}\left(n_{i}-\pi_{i}\right)}{\left[\pi_{i}+\eta_{c}\left[e\left(n_{i}-1\right)+1-\pi_{i}\right]\right]^{2}} \geq 0, \\
& \frac{\partial\left(\frac{\partial \pi_{i}}{\partial n_{i}}\right)}{\partial \eta_{c}}=\frac{\pi_{i}}{n_{i}} \frac{(1-e)\left[e\left(n_{i}-1\right)+1-\pi_{i}\right]}{\left[\pi_{i}+\eta_{c}\left[e\left(n_{i}-1\right)+1-\pi_{i}\right]\right]^{2}} \geq 0 .
\end{aligned}
$$

For comparative statics across equilibria, we need to take account of the response of $L$ which is the same as imposing the restriction in equation (6). To see that nothing changes qualitatively, consider an increase in $n_{x}$ in local government $x$ when $n_{x}$ has a positive within equilibrium effect on $\pi_{x}$. The increase in $\pi_{x}$ then increases $l_{x}$ when $L$ is kept constant, as

\footnotetext{
${ }^{a}$ A sufficient condition for existence of an interior and unique equilibrium is $e \leq c^{\prime}\left(l_{i j}\right)^{*} L / G$. The proof parallels Esteban and Ray (2001) proof of existence and uniqueness of an equilibrium for their equation (9).
} 
$\pi_{x}=1_{x} / L$. Now, allow $L$ to adjust to its new equilibrium value. This adjustment must be positive since $L=l_{x}+\sum_{i \neq x}^{m} l_{i}$ and since $l_{i}$ is kept constant for $i \neq x$. Then $\pi_{i}$ must decrease for $i \neq x$. But then $\pi_{x}$ must increase for equation (6) to hold, and the positive within equilibrium pattern also holds across equilibria. Same reasoning holds when the within equilibrium relationship is non-positive. QED.

Proof of proposition 2. We can derive grant dissipation by summing the within equilibrium condition in equation (A1) over all local governments $i$ and make use of equation (6). We then get the grant-dissipation condition:

$$
\frac{L}{G}=\frac{e(N-m)+m-1}{\sum_{i}^{m} n_{i} c^{\prime}\left(l_{i j}\right)} .
$$

QED. 


\section{REFERENCES}

Almenberg, J. (2007), "Kortslutna Signaler: Vad som Sägs och Inte Sägs om Inkomstutjämningen Mellan Kommuner", in Karlson, N. and J. Nergelisus ed. Federalism på Svenska, Stockholm, Förlaget Ratio.

Angrist, J. (1991), "Grouped Data Estimation and Testing in Simple Labor Supply Models", Journal of Econometrics 47, 243-266.

Angrist, J. and A. Kreuger (2001), "Instrumental Variables and the Search for Identification: From Supply and Demand to Natural Experiments", Journal of Economic Perspectives $15,69-85$.

Atlas, C. M., T. W. Gilligan, R. J. Hendershott, and M.A. Zupan (1995), "Slicing the Federal Government Net Spending Pie: Who Wins, Loses and Why", American Economic Review 85, 624-629.

Baqir, R. (2002), "Districting and Government Overspending," Journal of Political Economy $110,1318-1354$.

Borch, R., and S. Owings (2001), "The Political Economy of Intergovernmental Grants", Regional Science and Urban Economics 33, 139-156.

Card D., and D. Lee (2008), "Regression Discontinuity Inference with Specification Error", Journal of Econometrics 142, 655-674.

Cox, G. W. and M. D. McCubbins (1986), "Electoral Politics as a Redistributive Game", Journal of Politics 48. 370-89.

Dahlberg, M., and E. Johansson (2002), “On the Vote-Purchasing Behavior of Incumbent Governments", American Political Science Review 96, 27-40.

Dahlberg, M., E. Mörk, J. Rattsø, and H. Ågren (forthcoming), “Using a Discontinuous Grant Rule to Identify the Effect of Grants on Local Taxes and Spending”, Journal of Public Economics.

Esteban, J. and D. Ray (2001), "Collective Action and the Group Size Paradox", American Political Science Review 95, 663-672.

Gawande, K. and U. Bandyopadhyay (2000), "Is Protection for Sale? Evidence on the Grossman-Helpman Theory of Endogenous Protection", Review of Economics and Statistics 82, 139-152

Gilligan, T. W., and J. G. Matsusaka (1995), "Deviations from Constituent Interests: The Role of Legislative Structure and Political Parties in the States," Economic Inquiry 33, $383-401$. 
Goldberg P. K. and G. Maggi (1999), "Protection for Sale: An Empirical Investigation”, American Economic Review 89, 1135-1155.

Grossman, P. J. (1994), “A Political Theory of Intergovernmental Grants”, Public Choice 78, 295-303.

Hoxby, C. (2000), “The Effects of Class Size on Student Achievements: New Evidence from Population Variation", Quarterly Journal of Economics 115, 1239-85.

Imbens, G. and T. Lemieux (2007), "Regression Discontinuity Designs: A Guide to Practice", NBER Working Paper 13039.

Jansson, E. (1990), “'Värre Än Robin Hood Skatten', Kommunförbundets Förslag Får Kritik”, Expressen, January 14.

Johansson, E. (2003), "Intergovernmental Grants as a Tactical Instrument: Empirical Evidence from Swedish Municipalities", Journal of Public Economics 87, 883-915.

Jordahl, H. (2002), “The Impact of Grants on Election Outcomes: Evidence from Swedish Municipalities", Essays on Voting Behavior, Labor Market Policy and Taxation, Doctoral Dissertation, Uppsala University, Uppsala.

Katz, E., S. Nitzan and J. Rosenberg (1990), "Rent-Seeking for Pure Public Goods", Public Choice 65, 49-60.

Klintbom, H., F. Johnsson, and J. Lundgren (1994), "Sveket Mot Gotland, Enad Kommunledning Kräver att Regeringen Slutar Gynna Norrland”, Dagens Nyheter, July 24.

Knight, B. (2005), "Estimating the Value of Proposal Power", American Economic Review $95,1639-1652$.

Lee, D. (2008), "Randomized Experiments from Non-Random Selection in U.S. House Elections", Journal of Econometrics 142, 655-674.

Nitzan, S. (1991), “Collective Rent Dissipation”, Economic Journal 101, 1522-1534.

Olson, M. (1965), The Logic of Collective Action, Harvard University Press, Cambridge, MA. Pettersson-Lidbom, P. (2007), "Does the Size of the Legislature Affect the Size of Government? Evidence from Two Natural Experiments", Unpublished Manuscript, Stockholm University, Stockholm.

Porto, A., and P. Sanguinetti (2001), "Political Determinants of Intergovernmental Grants: Evidence from Argentina", Economics and Politics 13, 237-256.

Reading, D. (1973), "New Deal Activity and the States", Journal of Economic History 36, $792-810$. 
Riaz, K., J. F. Shogren and S. R. Johnson (1995), “A General Model of Rent-Seeking for Public Goods", Public Choice 82, 243-59.

Söderström, L. (1998), "Fiscal Federalism: The Nordic Way”, in Rattsø, J. ed., Fiscal Federalism and State-Local Finance, Edward Elgar, Northamption.

Sörbring, G. (2000), "Politiker Vill Pröva Robin Hood-Skatt”, Dagens Nyheter, December 20.

Sørensen, R. J. (2003), “The Political Economy of Intergovernmental Grants: The Norwegian Case", European Journal of Political Research 42, 163-195.

Tullock, G. (1967), "The Welfare Costs of Tariffs, Monopolies, and Theft”, Western Economic Journal 5, 224-232.

Tullock, G. (1980), "Efficient Rent-Seeking", in Buchanan, J. M., R. D. Tollison and G. Tullock Editors, Toward a Theory of the Rent-Seeking Society, 269-282, Texas A\&M University Press, College Station, Texas.

Wallis, J. J. (1996), "What Determines the Allocation of National Government Grants to the States?", NBER Historical Paper 90.

Van der Klaauw, W. (2002), "Estimating the Effect of Financial Aid Offers on College Enrollment: A Regression-Discontinuity Approach", International Economic Review 43, $1249-1287$.

Weingast, B. R., K. A. Shepsle. and C. Johnsen (1981), “The Political Economy of Benefits and Costs: A Neoclassical Approach to Politics," Journal of Political Economy 89, $642-664$.

Wright, G. (1974), "The Political Economy of New Deal Spending: An Econometric Analysis", Review of Economics and Statistics 56, 30-38. 
WORKING PAPERS*

Editor: Nils Gottfries

2007:4 Erik Post, Macroeconomic imbalances and exchange rate regime shifts. 38pp.

2007:5 Christian Andersson, Teacher density and student achievement in Swedish compulsory schools. 31pp.

2007:6 Thomas Aronsson, Sören Blomquist and Luca Micheletto, Where Should the Elderly Live and Who Should Pay for their Care? A Study in Demographics and Geographical Economics. 22pp.

2007:7 Sören Blomquist and Vidar Christiansen, Public Provision of Private Goods and Nondistortionary Marginal Tax Rates. 17pp.

2007:8 Marcus Eliason and Henry Ohlsson, Living to Save Taxes. 13pp.

2007:9 Åsa Ahlin and Eva Mörk, Effects of decentralization on school resources: Sweden 1989-2002. 31pp.

2007:10 Henry Ohlsson, The equal division puzzle - empirical evidence on intergenerational transfers in Sweden. 20pp.

2007:11 Daniel Hallberg and Mårten Lagergren, Moving in and out of public geriatric care in Sweden. 26pp.

2007:12 Per Engström, Wage Formation and Redistribution. 22pp.

2007:13 Henry Ohlsson, Tax avoidance - a natural experiment. 21pp.

2007:14 David Kjellberg and Erik Post, A Critical Look at Measures of Macroeconomic Uncertainty. 27pp.

2007:15 Mikael Carlsson and Andreas Westermark, Optimal Monetary Policy under Downward Nominal Wage Rigidity. 52pp.

2007:16 Robin Douhan and Anders Nordberg, Is the elephant stepping on its trunk? The problem of India's unbalanced growth. 33pp.

2007:17 Annika Alexius and Bertil Holmlund, Monetary Policy and Swedish Unemployment Fluctuations. 27pp.

2007:18 Meredith Beechey and Pär Österholm, The Rise and Fall of U.S. Inflation Persistence. 23pp.

2007:19 Henry Ohlsson and Donald Storrie, Long term effects of public policy for displaced workers in Sweden - shipyard workers in the West and miners in the North. 26pp.

\footnotetext{
* A list of papers in this series from earlier years will be sent on request by the department.
} 
2007:20 Niklas Bengtsson, How responsive is body weight to transitory income changes? Evidence from rural Tanzania. 38pp.

2007:21 Karin Edmark, Strategic Competition in Swedish Local Spending on Childcare, Schooling and Care for the Elderly. 38pp.

2007:22 Fredrik Johansson, How to Adjust for Nonignorable Nonresponse: Calibration, Heckit or FIML? 25pp.

2007:23 Henry Ohlsson, The legacy of the Swedish gift and inheritance tax, 18842004. 25pp.

2007:24 Ranjula Bali Swain and Fan Yang Wallentin, DOES MICROFINANCE EMPOWER WOMEN? Evidence from Self Help Groups in India. 26pp.

2007:25 Bertil Holmlund and Martin Söderström, Estimating Income Responses to Tax Changes: A Dynamic Panel Data Approach. 34pp.

2007:26 N. Anders Klevmarken, Simulating the future of the Swedish baby-boom generations. 60pp.

2007:27 Olof Åslund and Oskar Nordström Skans, How to Measure Segregation Conditional on the Distribution of Covariates. 17pp.

2007:28 Che-Yuan Liang, Is There an Incumbency Advantage or a Cost of Ruling in Proportional Election Systems? 20pp.

2007:29 Stefan Eriksson and Jonas Lagerström, Detecting discrimination in the hiring process: Evidence from an Internet-based search channel. 31pp.

2007:30 Helge Berger and Pär Österholm, Does Money Growth Granger-Cause Inflation in the Euro Area? Evidence from Out-of-Sample Forecasts Using Bayesian VARs. 32pp.

2007:31 Ranjula Bali Swain and Maria Floro, Effect of Microfinance on Vulnerability, Poverty and Risk in Low Income Households. 35pp.

2008:1 Mikael Carlsson, Johan Lyhagen and Pär Österholm, Testing for Purchasing Power Parity in Cointegrated Panels. 20pp.

2008:2 Che-Yuan Liang, Collective Lobbying in Politics: Theory and Empirical Evidence from Sweden. 37pp.

See also working papers published by the Office of Labour Market Policy Evaluation http://www.ifau.se/ 